\title{
Leydig Cells Encapsulation with Alginate-Chitosan: Optimization of Microcapsule Formation
}

\author{
Irmanida Batubara ${ }^{1}$, Devi Rahayu ${ }^{1}$, Kusdiantoro Mohamad ${ }^{2}$, Wahono Esthi Prasetyaningtyas ${ }^{2}$ \\ ${ }^{1}$ Department of Chemistry, Faculty of Mathematics and Natural Sciences, Bogor Agricultural University, Bogor, Indonesia \\ ${ }^{2}$ Department of Anatomy, Physiology and Pharmacology, Faculty of Veterinary Medicine, Bogor Agricultural University, Bogor, \\ Indonesia \\ Email: ime@ipb.ac.id
}

Received January 14, 2012; revised March 20, 2012; accepted April 3, 2012

\begin{abstract}
This research aimed to optimize the formation of microcapsules from alginate and chitosan for Leydig cells encapsulation. Alginate was used as the first coating agent while chitosan was the second layer. Various concentrations of alginate and $\mathrm{CaCl}_{2}$ were applied utilizing the extrusion method and the best concentration was determined based on their formation time, shape and diameter of microcapsules. Alginate microcapsule was applied with chitosan in various concentrations. The best chitosan concentration was selected based on its mechanical stability. The results showed that the minimum concentration of alginate was $1.5 \%(\mathrm{w} / \mathrm{v})$ with viscosity of $33.8 \mathrm{cPs}$, resulted to spherical microcapsules with diameters of $230-270 \mu \mathrm{m}$. The optimum concentration of chitosan as the second coating agent was $0.5 \%(\mathrm{w} / \mathrm{v})$, resulted to spherical microcapsules with mechanical stability of 4 hours. Leydig cells were trapped inside the microcapsule with a density that is proportional to the concentration of cells used in the encapsulation.
\end{abstract}

Keywords: Cell Encapsulation; Chitosan; Alginate; Microcapsule; Leydig Cells

\section{Introduction}

Cell encapsulation is a strategy to entrap the live cells within a semipermeable membrane [1]. It can be made simple and in large numbers while the loaded cells still have useful biological activity [2]. Encapsulation can prevent the contact between the cells and their surface antigens with the host's immune system components, while allowing the diffusion of nutrients and metabolites like hormones [3].

One of the interesting cells to entrap is the Leydig cell, which is especially useful for testosterone-replacement therapy. Leydig cells are responsible for the secretion of $95 \%$ of the total testosterone in the body [4]. Research on the encapsulation methods for Leydig cells had been performed. Macluf et al. [4] encapsulated Leydig cells encapsulation with alginate and poly-L-lysine while Baxter et al. [5] encapsulated Leydig cells in a polyethylene glycol diacrylate (PEDdA).

In this study, encapsulation was performed using alginate and chitosan as coating materials. Alginate, an anionic polysaccharide, has been widely used in the encapsulation process because it is a biocompatible and inexpensive material [6]. Alginate had also been used by Machluf et al. [4] as a core coating material of Leydig cells and by Capretto et al. [7] as coating material of Sertoli cells. On the other hand, chitosan is a positively charged polymer that could crosslink with anionic polymers such as alginate. Multiple coating systems, such as alginate-chitosan system, were used to reduce porosity and improve the stability of the capsule [8]. This study aims to optimize the formation of alginate-chitosan microcapsules with various concentrations of alginate, $\mathrm{CaCl}_{2}$, and chitosan based on physical properties and mechanical stability. The optimum condition was applied to Leydig cells.

\section{Experimental}

\subsection{Determination of Coating Agent Properties}

Osmolality and viscosity parameters were used to ensure that the coating agents had the same properties as the Leydig cells. Alginate solution was prepared at various concentrations of $0.5 \%, 1.0 \%, 1.5 \%$, and $2.0 \%(\mathrm{w} / \mathrm{v})$ in distilled water and phosphate saline buffer (PBS). Chitosan $(73.76 \%$ degree of acetylation and molecular weight: $3.7 \times 105 \mathrm{~g} / \mathrm{mol}$ ) solution was prepared at various concentrations of $0.5 \%, 1.0 \%, 1.5 \%, 2.0 \%(\mathrm{w} / \mathrm{v})$ in $1 \%$ $\mathrm{CH}_{3} \mathrm{COOH}$, while $\mathrm{CaCl}_{2}$ were made in $0.05,0.10,0.15$, and $0.20 \mathrm{M}$ in distilled water. The osmolality of all the solutions were determined by cryoscopic osmometer (Osmomat 030, Germany) and the viscosity was determined by Brokkfield viscometer. 


\subsection{Optimization of Core-Microcapsule Forming Condition}

Alginate (Sigma Aldrich) was used as the core-microcapsule using droplet formation of alginate- $\mathrm{CaCl}_{2}$ gel with extrusion method. Various concentrations of alginate $(0.5,1.0,1.5$, and $2.0(\mathrm{w} / \mathrm{v})$ in PBS) were dropped by micro pipette on various concentrations of $\mathrm{CaCl}_{2}$ $(0.05,0.10,0.15,0.20 \mathrm{M})$. Contact time between alginate and $\mathrm{CaCl}_{2}$ was performed for about 15 minutes to give time for microcapsule to form. The microcapsules were washed three times with phosphate saline. The microcapsule formation time, the shape and the diameter of microcapsules were observed under light microscope equipped with micrometer-scale lines. The minimum concentration of alginate and $\mathrm{CaCl}_{2}$ were selected for the next step experiment.

\subsection{Optimization of Second Layer Microcapsule}

Chitosan was used as the second layer of the microcapsule. The best core-microcapsule from the first experiment was put in various concentrations of chitosan $(0.5 \%$, $1.0 \%, 1.5 \%, 2.0 \%(\mathrm{w} / \mathrm{v})$ in $\left.1.0 \% \mathrm{CH}_{3} \mathrm{COOH}\right)$. Contact time between core-microcapsule with chitosan was about 6 minutes to give the new microcapsule form. The microcapsules were washed with distilled water and phosphate saline buffer. The optimum condition was selected by the mechanical stability test [9]. Briefly, 25 pieces of microcapsules were put in phosphate saline buffer $\mathrm{pH} 7.2$ for 15 minutes and then stirred with a magnetic stirrer at 500 rpm. The time to reach $50 \%$ damaged capsules was determined.

\subsection{Isolation of Leydig Cells}

The Leydig cells were isolated from the testicular tissue of Sprague Dawley rats on their puberty age of 8 weeks. Isolation and purification of Leydig cells were performed using the method of Chemes et al. [10] with some modifications. The tissue fragment (about $800 \mathrm{mg}$ ) were dissociated by mechanically and treated with a solution of $0.04 \%$ collagenase and $1.0 \mu \mathrm{g} / \mathrm{ml}$ trypsin inhibitor in the DPBS with some agitation at $34^{\circ} \mathrm{C}$ for $40 \mathrm{~min}$. After enzymatic digestion, the collagenase solution was diluted four times with DPBS and the small fragments were allowed to sediment for $2 \mathrm{~min}$. The supernatant was collected and centrifuged at room temperature for $3 \mathrm{~min}$ at $200 \times \mathrm{g}$, and the pellet was washed twice and then diluted in $500 \mu \mathrm{L}$ DPBS. The suspension contained the Leydig cells purified by use of a discontinuous five Percoll density gradient $(21 \%, 26 \%, 34 \%, 40 \%$ and $60 \%)$ and centrifuged at $400 \times \mathrm{g}$ for 15 min continuing by $800 \times$ $\mathrm{g}$ for $15 \mathrm{~min}$. The interface layer between $40 \%$ and $60 \%$ was collected and washed by DPBS three times to removed the percoll. Viability determined by the Tripan Blue dye and only the viablity higher than $90 \%$ that used for the encapsulation.

\subsection{Encapsulation of Leydig Cells}

Leydig cells were diluted in various concentrations, namely: $1 \times 10^{7}, 1 \times 10^{6}, 1 \times 10^{5}$, and $1 \times 10^{4}$ cells $/ \mathrm{ml}$ in alginate solution at the best concentration (from the previous experiment). Alginate solution containing Leydig cells was dropped with micropipette into the best concentration of $\mathrm{CaCl}_{2}$ solution to form the core-microcapsule. After washing with phosphate buffer, the core microcapsules were placed in chitosan solution at the optimum condition. Microcapsules were then washed with citrate buffer and distilled water. The diameter of the microcapsule was observed with a light microscope equipped with a micrometer scale.

\section{Results and Discussion}

\subsection{Physical Coating Agent Properties}

To find the best concentration to form the microcapsule for encapsulating the Leydig cells, we focused on the osmolality and viscosity of the solutions used. Osmolality, the number of solute particles per liter solution, is an important property for cells due to its relation to the osmotic process on the cells. The cell has an osmolality range of $280-320 \mathrm{mosmol} / \mathrm{kg}$ [11]. At this osmolality the cell remains alive. A balanced osmolality properties of cells and the capsules will ensure that the cells are in good condition.

Osmolality properties of all solutions used are presented in Table 1. Alginate solution at the concentration of $0.5 \%-2.0 \%(\mathrm{w} / \mathrm{v})$ in distilled water has an osmolality value (less than $280 \mathrm{mosmol} / \mathrm{kg}$ ) lower than the cell's osmolality, while in buffer solution the osmolality of alginate solution was increased (357 - $618 \mathrm{mosmol} / \mathrm{kg}$ ). The increase of osmolality property of the solution might be due to the presence of ions contained in the buffer. In PBS, alginate solution had a higher osmolality property compared to the cell's osmolality. This result suggested to prepare the alginate solution with distillated water and adjusts the osmolality to 300 mosmol/ $\mathrm{kg}$ with $\mathrm{NaCl}$.

The osmolality of $\mathrm{CaCl}_{2}$ solution was ranging from 75 $249 \mathrm{mosmol} / \mathrm{kg}$ while that chitosan ranged from $33-123$ mosmol $/ \mathrm{kg}$. The osmolality of $\mathrm{CaCl}_{2}$ and chitosan solutions were lower compared to the cells' osmolality, but the osmolality of $\mathrm{CaCl}_{2}$ and chitosan had less effect on the coating process because the cells were not directly in contact with these solutions. Leydig cells were coated in alginate solution, so that the osmolality of alginate must be adapted to the cells' environmental condition.

The other parameter to be considered for cell coating 
Table 1. Osmolality and viscosity properties of the solution used.

\begin{tabular}{|c|c|c|c|c|}
\hline \multirow{2}{*}{ Solution } & \multirow{2}{*}{$\begin{array}{l}\text { Concentration } \\
(\%)(b / v)\end{array}$} & \multicolumn{2}{|c|}{ Osmolality (mosmol/kg) } & \multirow{2}{*}{$\begin{array}{l}\text { Viskositas } \\
\text { (cPs) }\end{array}$} \\
\hline & & $\begin{array}{l}\text { In distillate } \\
\text { water }\end{array}$ & In PBS & \\
\hline \multirow{4}{*}{ Alginate } & 0.5 & 78 & 357 & 10.5 \\
\hline & 1.0 & 141 & 504 & 17.6 \\
\hline & 1.5 & 147 & 534 & 33.8 \\
\hline & 2.0 & 240 & 618 & 52.1 \\
\hline \multirow{4}{*}{ Chitosan } & 0.5 & \multicolumn{2}{|l|}{33} & 8.76 \\
\hline & 1.0 & \multicolumn{2}{|l|}{72} & 13.72 \\
\hline & 1.5 & \multicolumn{2}{|l|}{90} & 24.76 \\
\hline & 2.0 & \multicolumn{2}{|c|}{123} & 43.38 \\
\hline \multirow{4}{*}{$\mathrm{CaCl}_{2}$} & 0.05 & \multicolumn{2}{|l|}{75} & \\
\hline & 0.10 & \multicolumn{2}{|l|}{135} & \\
\hline & 0.15 & \multicolumn{2}{|c|}{204} & \\
\hline & 0.20 & \multicolumn{2}{|l|}{249} & \\
\hline
\end{tabular}

material is viscosity. The higher the viscosity of the polymer solution, the faster the formation of the capsule. Viscosity of the polymer was also reported to have a relation with the release capacity of material trapped [12]. The higher the viscosity of polymer, the slower the release time of the material trapped. Viscosity of alginate solution was ranging from 10.5 to $52.1 \mathrm{cPs}$ whereas the viscosity of chitosan solution ranged from 8.76 to 43.88 cPs (Table 1). Viscosity of the solution increased when the concentration of the solution increased. Based on the results, the highest viscosity of alginate solution was at $2.0 \%$.

\subsection{Optimization of The Core-Microcapsule Forming Condition}

The encapsulation process started with the formation of the core microcapsule using the alginate solution. The core microcapsule formed at different concentrations of alginate solution is shown in Figure 1. Irregular capsules were formed when low concentrations $(0.5 \%$ and $1.0 \%$ $(\mathrm{w} / \mathrm{v}))$ of alginate were dropped to $\mathrm{CaCl}_{2}$ solution. The spherical microcapsule was formed when alginate concentration used was $1.5 \%$. At this concentration, viscosity of alginate solution was $33.8 \mathrm{cPs}$. It means the minimum threshold of droplet formation of the core microcapsule to produce spherical microcapsule was $33.8 \mathrm{cPs}$. This is consistent with the results of Goosen et al. [13] which showed that the minimum viscosity of alginate solution in order to form a spherical microcapsule is 30 cPs.
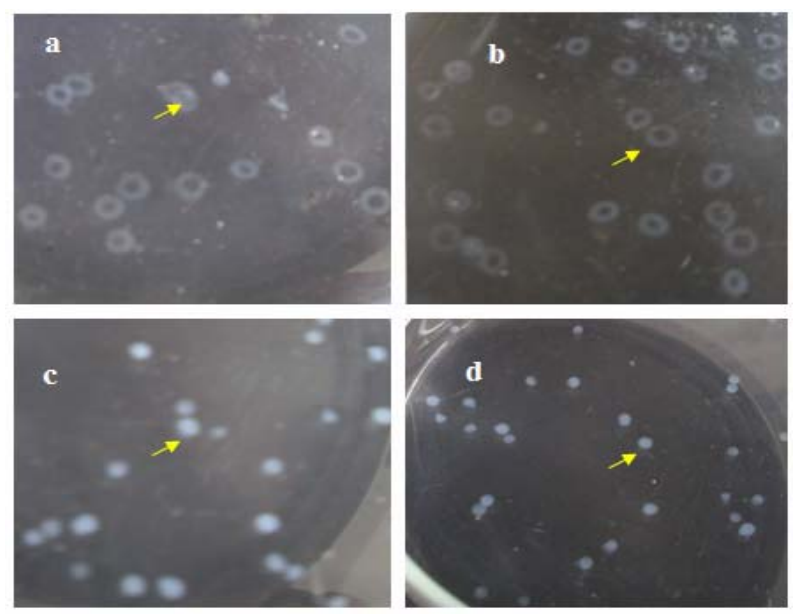

Figure 1. Core microcapsule on different concentration of alginate: (a) $0.5 \%$; (b) $1.0 \%$; (c) $1.5 \%$, and (d) $2.0 \%$, arrow is microcapsule.

The diameter of microcapsules at different concentrations of alginate and $\mathrm{CaCl}_{2}$ is shown in Figure 2. The diameter of microcapsules which were formed at $0.5 \%$ concentration of alginate could not be determined because the capsules were irregularly shaped. Microcapsules which were formed at $1.0 \%$ concentration of alginate ranged from 310 to $322 \mu \mathrm{m}$, while at $1.5 \%$ and $2.0 \%$ concentrations of alginate were $205-258 \mu \mathrm{m}$. According to Stuivers (2001), the suitable microcapsule size for Leydig cell encapsulation was $200-400 \mu \mathrm{m}$ [14]. It means alginate concentrations of $1.0 \%, 1.5 \%$, and $2.0 \%$ $(\mathrm{w} / \mathrm{v})$ are suitable for Leydig cells. Unlike the concentration of alginate, concentration of $\mathrm{CaCl}_{2}$ had no significant correlation with the diameter size and shape of microcapsules.

Poly-anionic complex formation between alginate and divalent cations like $\mathrm{CaCl}_{2}$ is spontaneous. The concentration of $\mathrm{CaCl}_{2}$ had significant correlation with the hardening time of the microcapsule (Figure 3). The higher the concentration of $\mathrm{CaCl}_{2}$, the faster the time for microcapsule formation. The $0.15 \mathrm{M}$ concentration of $\mathrm{CaCl}_{2}$ is the optimum concentration in the formation of microcapsule obtained in this study because it gave spherical microcapsules and short hardening time. The alginate concentration also influenced the hardening time. The hardening of $0.5 \%$ alginate gel took 1519 seconds while those of $1.5 \%$ and $2.0 \%$ took less than a minute (5 - 34 seconds). Based on this result, for the next experiment, the concentration for alginate was $1.5 \%(\mathrm{w} / \mathrm{v})$, because this concentration is the lowest concentration which can make a good shape and short hardening time of microcapsules.

Based on the shape, diameter and hardening time of alginate gel resulting from different concentrations of alginate and $\mathrm{CaCl}_{2}$, the best concentration of alginate was 


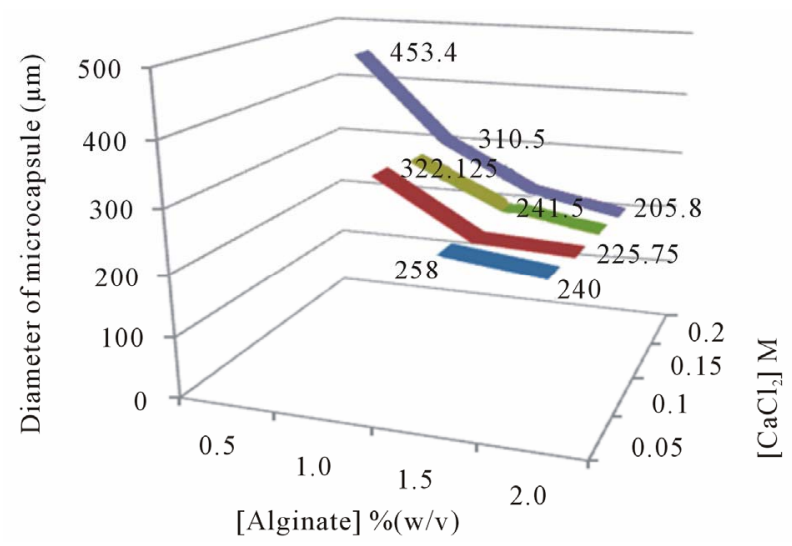

Figure 2. Diameter of core microcapsule on different concentrations of alginate and $\mathrm{CaCl}_{2}$.

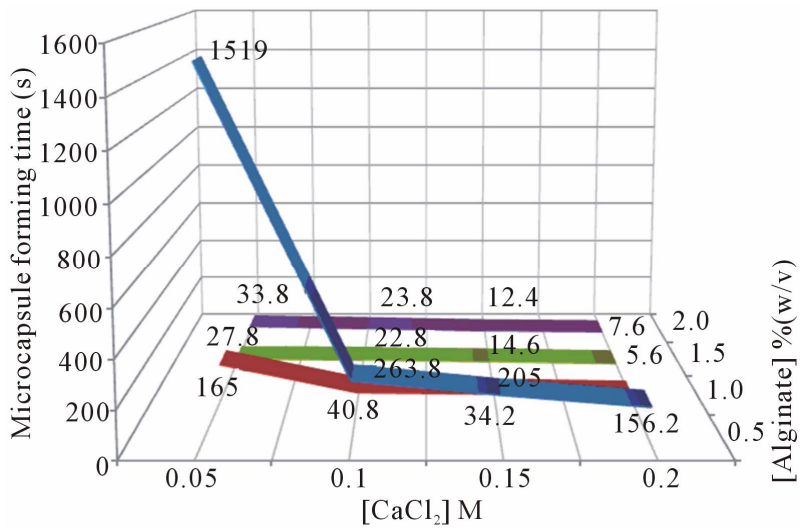

Figure 3. Microcapsule forming time on different concentration of alginate and $\mathrm{CaCl}_{2}$.

$1.5 \%(\mathrm{w} / \mathrm{v})$ and $0.15 \mathrm{M}$ for $\mathrm{CaCl}_{2}$. The concentration of alginate utilized in this study was higher than used by Machluf et al. $(1.2 \%, \mathrm{w} / \mathrm{v})[3]$.

\subsection{Optimization of Second Layer Microcapsule}

The alginate gel microcapsule was inserted into chitosan solution in different concentrations. The color of alginate gel changed into yellow after being inserted into the chitosan solution. The change of color means there was a bind between chitosan and the alginate. Friedli and Schalanger stated that the alginate and chitosan can bind spontaneously in less than 5 minutes [6]. Alginate gel as a core microcapsule will bond with amine groups on the chitosan. Interaction of alginate with chitosan is a cationic crosslinking of $\mathrm{NH}_{3}{ }^{+}$derived from chitosan and anionic $\mathrm{COO}^{-}$derived from alginate.

The optimum concentration of chitosan was selected by its mechanical stability. A mechanical stability property of microcapsule is one aspect of the success of cell encapsulation technique in addition to the permeability properties of the capsule, immune system protection, and biocompatibility. The mechanical stability of the micro- capsules is important not only to determine the durability of the capsule during production or treatment but also to maintain the membrane integrity of microcapsule [15]. The mechanical stability test was performed by mixing the alginate-chitosan gel in PBS solution in $500 \mathrm{rpm}$ of stirring speed. The result of percent of damaged cells in different concentrations of chitosan is presented in Figure 4. Alginate microcapsules coated with chitosan at concentrations of $0.5 \%$ and $1.0 \%(\mathrm{w} / \mathrm{v})$ have more than $50 \%$ damage after stirring for 4 hours $(59 \%$ and $64 \%$, respectively). The alginate-chitosan microcapsules at $2.0 \%$ concentration of chitosan had $51 \%$ damage after stirring for 11 hours. The viscosity of chitosan solution was determined to investigate the effect of viscosity on the mechanical stability of microcapsules. Coating the core microcapsule with high concentration of chitosan (2\%) gave a thicker coating so it could be more stable for mechanical treatment. Chitosan in low concentrations had low viscosities and tend to be more easily damaged by mechanical treatment.

The second coating thickness also affects the microcapsule. Microcapsules became wrinkled when incorporated with chitosan in high concentration $(2.0 \%)$. This is caused by osmotic phenomenon. If the outer part of the microcapsule (chitosan) has higher concentration, it allows water from the inner part (alginate) of the microcapsule to move out to the outer side and the microcapsule shrivels. Therefore, the coating with the $0.5 \%$ chitosan concentration is best for encapsulation of Leydig cells because it will not affect the osmotic balance of the cells.

\subsection{Encapsulation of Leydig Cells}

Encapsulation of Leydig cells was performed on sterile condition of $1.5 \%$ alginate and $0.5 \mathrm{M} \mathrm{CaCl}_{2}$. The results of Leydig cells encapsulation showed that the cells can be trapped into the coated core alginate microcapsules. The resulting microcapsules were white and spherical.

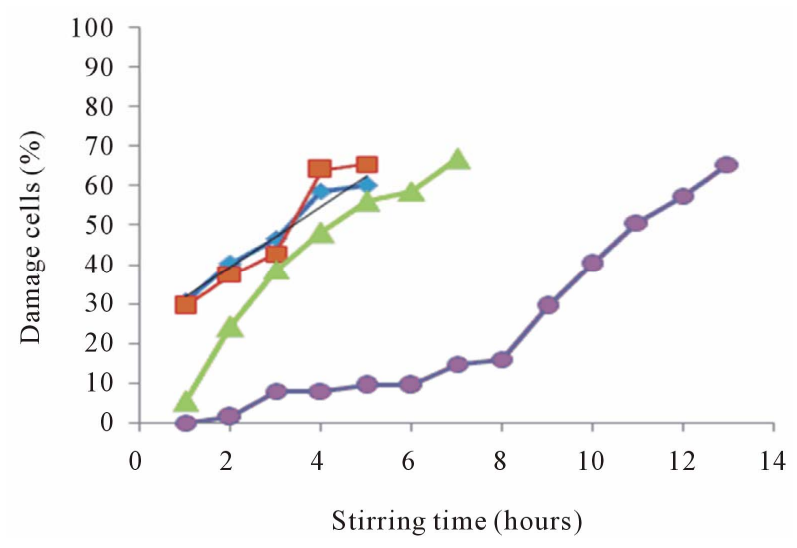

Figure 4. Mechanical stability of capsules on different concentration of chitosan $(\diamond: 0.5 ; \square: 1.0 ; \triangle: 1.5 ;$ dan $\circ: 2.0 \%$ (w/v)). 


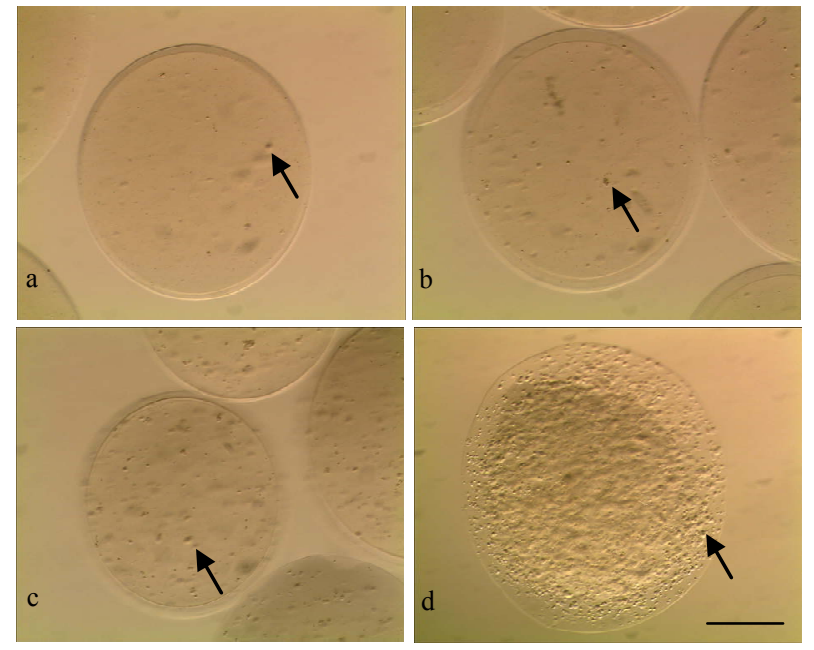

Figure 5. Microcapsules with different concentrations of Leydig cells: (a) $1 \times 10^{4}$; (b) $1 \times 10^{5}$; (c) $1 \times 10^{6}$; and (d) $1 \times$ $10^{7}$ cells $/ \mathrm{mL}$; arrow $=$ Leydig-cell; bar $=50 \mu \mathrm{m}$.

The microcapsules were successfully produced at a diameter range of $230-270 \mu \mathrm{m}$. Leydig cells trapped in the core of microcapsules were spread (Figure 5). Cell density in the microcapsule was proportional with the cell concentration used. Microcapsules with the cell concentration of $1 \times 10^{7}$ cells $/ \mathrm{mL}$ had a high cell density, almost all parts of the microcapsule was covered by cells.

\section{Conclusion}

The minimum concentration of alginate as a core for the microcapsule formation was $1.5 \%(\mathrm{w} / \mathrm{v})$, i.e. with a viscosity of $30 \mathrm{cPs}$ and a concentration of $0.15 \mathrm{M} \mathrm{CaCl}_{2}$. This condition resulted to round and white microcapsules with diameters of $230-370 \mu \mathrm{m}$. The stability of coating microcapsules increased with the increasing chitosan concentration. Encapsulation can be applied to the cell, i.e. Leydig cells. Leydig cells were trapped inside the microcapsules. The density of trapped cells in the capsule was proportional to the concentration of the cells applied.

\section{Acknowledgements}

This work was supported by Higher Education Directorate of the Ministry of Education Republic of Indonesia (Hibah Bersaing No: XVIII/1).

\section{REFERENCES}

[1] M. L. Torre, M. Faustini, K. M. E. Attilio and D. Vigo, "Cell Encapsulation in Mammal Reproduction," Recent Patents on Drug Delivery \& Formulation, Vol. 1, No. 1, 2007, pp. 81-85. doi: 10.2174/187221107779814078

[2] T. M. S. Chang, "Semipermeable Microcapsules," Science, Vol. 146, No. 3643, 1964, pp. 524-525. doi:10.1126/science.146.3643.524
[3] M. Machluf, A. Orsola and A. Atala, "Controlled Release of Therapeutic Agents: Slow Delivery and Cell Encapsulation," World Journal of Urology, Vol. 18, No. 1, 2000, pp. 80-83. doi: $10.1007 / \mathrm{s} 003450050014$

[4] M. Machluf, A. Orsola, S. Boorjian, R. Kershen and A. Atala, "Microencapsultaion of Leydig Cells: A System for Testosterone Supplementation," General Endocrinology, Vol. 144, No. 11, 2003, pp. 4975-4979. doi:10.1210/en.2003-0411

[5] B. Baxter, T. Eng and J. Zechlinski, "Microcapsulation of Cells," BME 400 University of Wisconsin-Madison Final Report, Dec 7, 2005. pp 15-16.

http://homepages.cae.wisc.edu/ bme200/microencapsulat ion_fall05/reports/BME_400_Microencapsulation_Final_ Report.pdf

[6] A. C. Friedli and I. R. Schlager, "Demonstrating Encapsulation and Release: A New Take on Alginate Complexation and the Nylon Rope Trick," Journal of Chemical Education, Vol. 82, No. 7, 2005, pp. 1017-1020. doi:10.1021/ed082p1017

[7] L. Capretto, S. Mazzitelli, G. Luca and C. Nastruzzi, "Preparation and Characterization of Polysaccharidic Microbeads by a Microfluidic Technique: Application to the Encapsulation of Sertoli Cells," Acta Biomaterialia, Vol. 6, No. 2, 2010, pp. 429-435. doi:10.1016/j.actbio.2009.08.023

[8] C. M. Silva, A. J. Riberio, M. Figueiredo, D. Ferreira and F. Veiga, "Microencapsulation of Hemoglobin in Chitosan-Coated Alginate Microspheres Prepared by Emulsification/Internal Gelation," The AAPS Journal, Vol. 7, No. 4, 2006, pp. E903-E913. doi:10.1208/aapsj070488

[9] J.-H. Zhu, X.-W. Wang, S. Ng, C.-H. Quek, H.-T. Ho, X.-J. Lao and H. Yu, "Encapsulating Live Cells with WaterSoluble Chitosan in Physiological Conditions," Journal of Biotechnology, Vol. 117, No. 4, 2005, pp. 355-365. doi:10.1016/j.jbiotec.2005.03.011

[10] H. Chemes, S. Cigorraga, C. Begadá, H. Schteingart, R. Rey and E. Pellizzari, "Isolation of Human Leydig Cell Mesenchymal Precursors from Patient with the Androgen Insensitivity Syndrome: Testosterone Production and Response to Human Chorionic Gonadotropin Stimulation in Culture," Biology of Reproduction, Vol. 46, No. 5, 1992, pp. 793-801. doi:10.1095/biolreprod46.5.793

[11] V. T. Nguyen, S. Kure-Bayashi, H. Harayama, T. Nagai and M. Miyake, "Stage Spesific Effects of the Osmolality of a Culture Medium on the Development of Parthenogenetic Diploids in Pig" Theriogenology, Vol. 59, No. 3, 2003, pp. 719-734. doi:10.1016/S0093-691X(02)01085-3

[12] G. Murtaza, M. Ahamd, N. Akhtar and F. Rasool, "A Comparative Study of Various Microencapsulation Techniques: Effect of Polymer Viscosity on Microcapsule Characteristics," Pakistan Journal of Pharmaceutical Science, Vol. 22, No. 3, 2009, pp. 291-300.

[13] M. F. A. Goosen, G. M. O'Shea and M. F. Sun, "Microencapsulation of Living Tissue and Cells," US Patent No. 4,806,355, 1998.

http://www.google.com/patents?id=KARLAAAAEBAJ\& $\mathrm{pg}=\mathrm{PA} 6 \& \mathrm{dq}=$ microcapsules + of + living + tissue $\& \mathrm{hl}=\mathrm{en} \& \mathrm{sa}$ $=$ X\&ei=ZozNT6CiFI_imAWKv7G4Aw\&ved=0CDQQ6 
AEwAA\# $\mathrm{v}=$ onepage $\& \mathrm{q}=$ microcapsules $\% 20 \mathrm{of} \%$ 20living $\% 20$ tissue $\& \mathrm{f}=$ false

[14] I. Stuiver, "Microencapsulation of Islet for the Treatment of Type 1 Diabetes," Workshop Encapsulation and Immunoprotective Strategies of Islet Cells Proceeding, Wash- ington DC, 6-7 December 2001, p. 18.

[15] H. Uludag, P. De Vos and P. A. Tresco, "Technology of Mammalian Cell Encapsulation," Advanced Drug Delivery Reviews, Vol. 42, No. 1-2, 2000, pp. 29-64. doi:10.1016/S0169-409X(00)00053-3 